\title{
Axonal Localization of Neuritin/CPG15 mRNA in Neuronal Populations through Distinct 5' and 3' UTR Elements
}

\author{
Tanuja T. Merianda, ${ }^{1}$ Cynthia Gomes, ${ }^{1}$ Soonmoon Yoo, ${ }^{2}$ Deepika Vuppalanchi, ${ }^{3}$ and Jeffery L. Twiss ${ }^{1,4}$ \\ ${ }^{1}$ Department of Biology, Drexel University, Philadelphia, Pennsylvania 19104, ${ }^{2}$ Nemours Biomedical Research, Alfred I. duPont Hospital for Children, \\ Wilmington, Delaware 19803, ${ }^{3}$ Department of Biological Sciences, University of Delaware, Newark, Delaware 19716, and ${ }^{4}$ Department of Biological \\ Sciences, University of South Carolina, Columbia, South Carolina 29208
}

\begin{abstract}
Many neuronal mRNAs are actively transported into distal axons. The $3^{\prime}$ untranslated regions (UTRs) of axonal mRNAs often contain cues for their localization. The 3' UTR of neuritin mRNA was shown to be sufficient for localization into axons of hippocampal neurons. Here, we show that neuritin mRNA localizes into axons of rat sensory neurons, but this is predominantly driven by the $5^{\prime}$ rather than $3^{\prime}$ UTR. Neuritin mRNA shifts from cell body to axon predominantly after nerve crush injury, suggesting that it encodes a growth-associated protein. Consistent with this, overexpression of neuritin increases axon growth but only when its mRNA localizes into the axons.
\end{abstract}

\section{Introduction}

Neurons target mRNAs for transport into axons and dendrites as a means to spatially and temporally regulate protein levels (Jung et al., 2012). Most studies have indicated that neurons use elements in $3^{\prime}$ untranslated regions (UTRs) for localizing mRNAs. For example, alternate $3^{\prime}$ UTRs in BDNF and Importin $\beta 1$ generate mRNAs that are cell body restricted or localized to processes, and knock-out of the localizing 3' UTR sequences causes functional changes in mice (An et al., 2008; Perry et al., 2012). $\beta$-Actin mRNA is targeted to neuronal processes through its $3^{\prime}$ UTR (Zhang et al., 2001; Tiruchinapalli et al., 2003); this occurs in vivo, is regulated by extracellular stimuli, and requires binding by zip code binding protein 1 (ZBP1; Willis et al., 2007, 2011; Donnelly et al., 2011). ZBP1 binding also restricts how much $\beta$-actin mRNA localizes into sensory axons, because ZBP1 is expressed at low levels in these neurons (Donnelly et al., 2011). These and other studies point to the importance of $3^{\prime}$ UTR elements for post-transcriptional regulation.

We recently reported that neural membrane protein 35 (NMP35) mRNA is transported into axons through its $3^{\prime}$ UTR (Merianda et al., 2013), but its transport is not limited like was seen for $\beta$-actin (Donnelly et al., 2011). Here, we show that neuritin mRNA shifts it localization after nerve injury similar to NMP35. However, neuritin mRNA shows different localization

\footnotetext{
Received March 3, 2013; revised June 20, 2013; accepted July 16, 2013.

Author contributions: T.T.M., C.G., and J.L.T. designed research; T.T.M., C.G., S.Y., and D.V. performed research; D.V. contributed unpublished reagents/analytic tools; T.T.M., C.G., S.Y., and J.L.T. analyzed data; T.T.M. and J.L.T. wrote the paper.

This work was supported by funds from Paralyzed Veterans of America (2442), NIH (R01-NS041596), and the Dr Miriam and Sheldon G. Adelson Medical Research Foundation. Elly Nedivi (Massachusetts Institute of Technology, Cambridge, MA) provided the CDNA for murine CPG15 and Erin Schuman (Max Planck Institute for Brain Research, Frankfurt, Germany) provided GFP myr.

The authors declare no competing financial interests.

Correspondence should be addressed to Dr Jeffery L. Twiss, 715 Sumter Street, CLS 707, University of South Carolina, Columbia, SC 29208. E-mail: twiss@mailbox.sc.edu.

D. Vuppalanchi's present address: Healthcare Communications Group, Carmel, IN 46032

DOI:10.1523/JNEUROSCI.0962-13.2013

Copyright $\odot 2013$ the authors $\quad 0270-6474 / 13 / 3313735-08 \$ 15.00 / 0$
}

elements for CNS versus PNS axons; its 3' UTR drives localization in hippocampal neurons and $5^{\prime}$ UTR drives localization in sensory axons. Moreover, growth-promoting activity of neuritin protein in dorsal root ganglia (DRG) neurons requires axonal targeting through the mRNA's 5' UTR.

\section{Materials and Methods}

Animal procedures and neuronal cultures. Animal procedures were approved by institutional Animal Care and Use Committees. For injury, the sciatic nerve of 150-225 g male Sprague Dawley rats was crushed at mid-thigh level. Dissociated cultures were prepared from L4-6 DRG as described previously (Twiss et al., 2000). DRGs were plated on coverslips for imaging and on porous membranes (BD Falcon) for isolation of axons (Zheng et al., 2001). RNA stability was tested in severed axons treated with $20 \mu \mathrm{M}$ cyclosporin A (CsA; Merianda et al., 2013). Hippocampal cultures were prepared from postnatal $(\mathrm{P})$ day 0 rat pups (Gomes et al., 2011).

DRGs were transfected with Rat Neuron Nucleofector kit (Lonza) (Vuppalanchi et al., 2010). Transfected DRGs were analyzed at $3 \mathrm{~d}$ in vitro (DIV). Hippocampal neurons were transfected using Basic Neuron SCN Nucleofector kit (Lonza) and analyzed at 7-8 DIV.

A pool of synthetic siRNAs targeting rat neuritin (Nrn1; L-098939-010020) was designed using Dharmacon siDesign Center. DRGs were transfected $1 \mathrm{~d}$ after plating with $200 \mathrm{~nm}$ siRNA or nontargeting siControl (siCon) using DharmaFECT3 (Dharmacon; Merianda et al., 2013). RTPCR was used to test for efficiency of depletion at 4 DIV (see below).

DNA constructs. Diffusion-limited GFP $\left(\mathrm{GFP}^{\mathrm{myr}}\right)$ was used to test activity of rat Nrn1 (GenBank NM_053346) 5' and 3' UTRs. $\gamma$-actin (GenBank NM_001127449) 3' UTR was used as control. cDNAs were cloned into GFP ${ }^{\text {myr }}$ plasmid replacing $3^{\prime}$ and 5' UTRs of calmodulin kinase II $\alpha$ (CaMKII $\alpha$; Aakalu et al., 2001). For protein expression, nucleotides (nt) 1-527 of rat Nrn1 were cloned into pAcGFP1-N3 (Clontech). Nrn1 GPI sequence (nt 528-617) was inserted at the $\mathrm{C}$ terminus of AcGFP (herein, referred to as "GFP"); 3' UTR of Nrn1 was inserted immediately downstream. pAcGFP1-N3 UTRs were used as control. All cloned cDNAs were generated by RT-PCR as below and sequence validated.

RNA extraction and PCR. DRGs were cultured for $16 \mathrm{~h}$ and RNA was isolated using RNAqueous or RNAqueous ${ }^{\text {Micro }}$ (Ambion). Axon RNA was normalized for protein content by NanoOrange (Invitrogen). Other preparations were normalized for RNA content by RiboGreen (Invitro- 
A

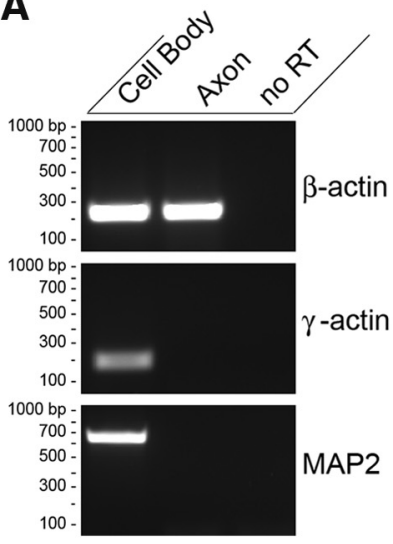

D

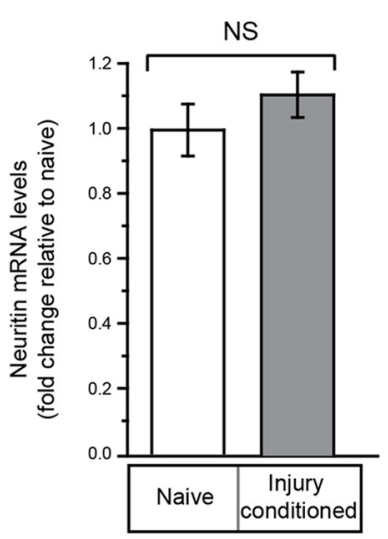

B

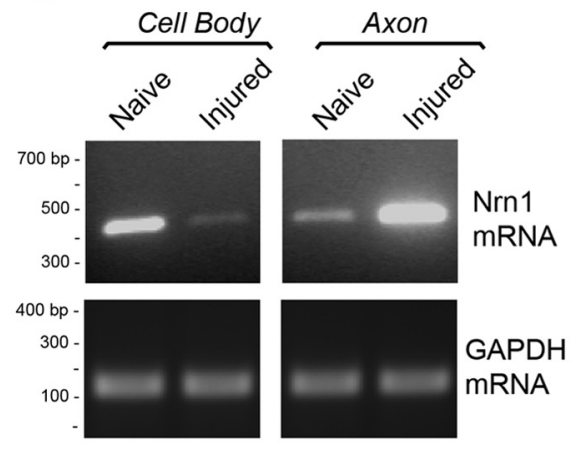

C

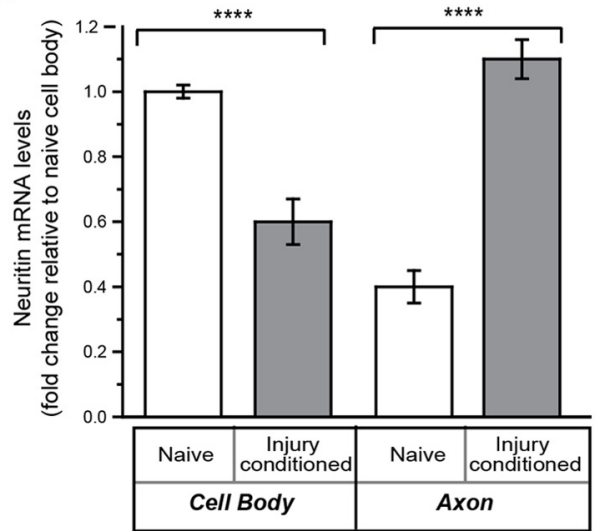

E

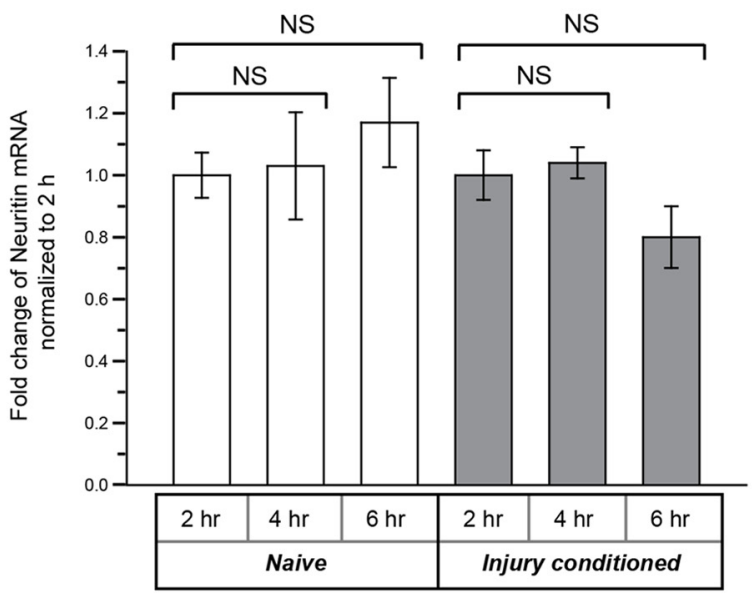

F
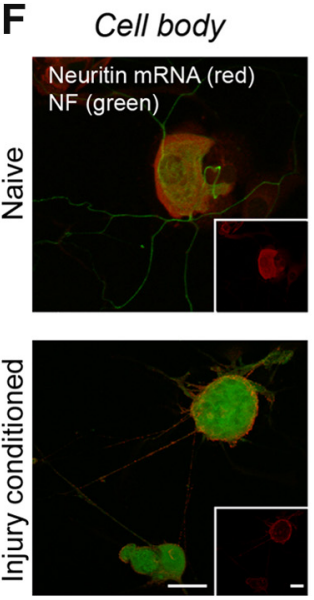

H
Axon
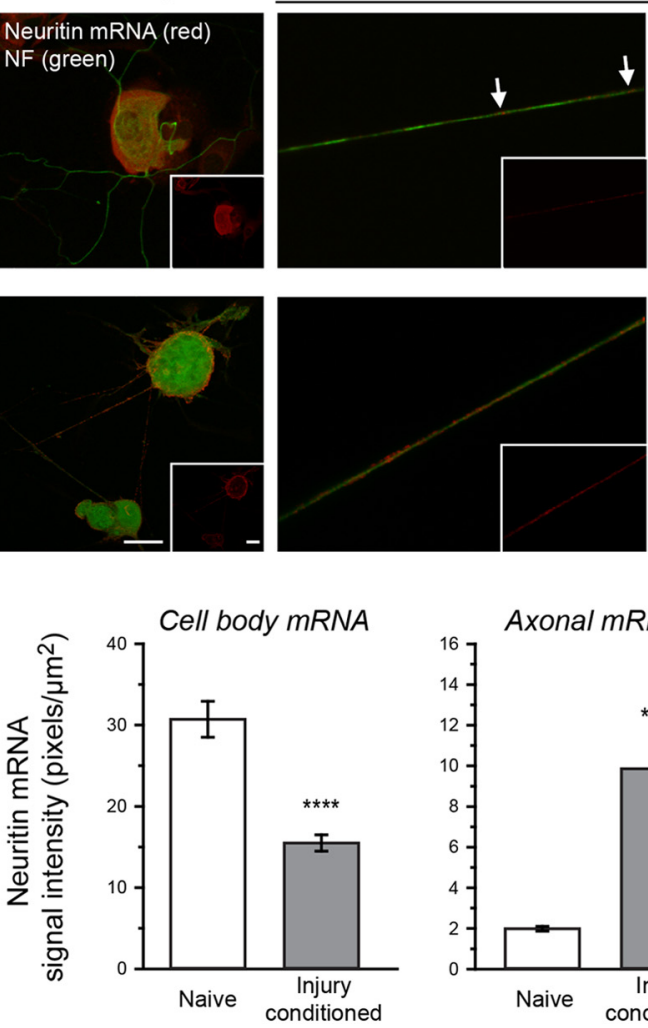

Axonal mRNA

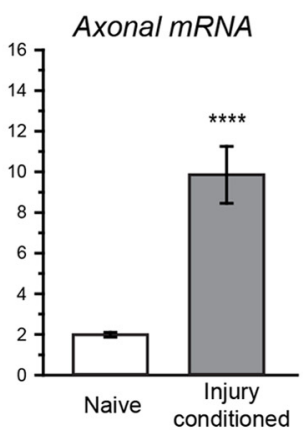

G
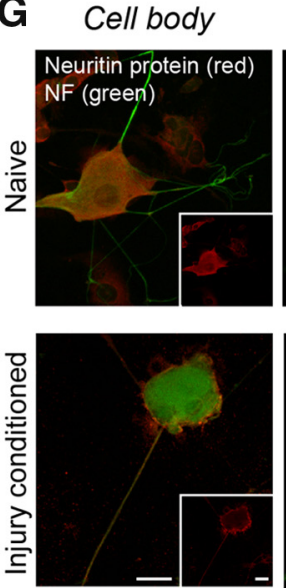

Cell body protein

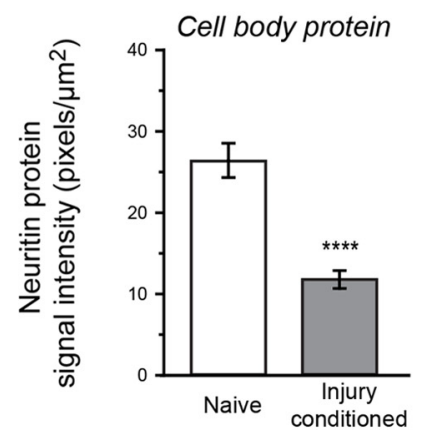

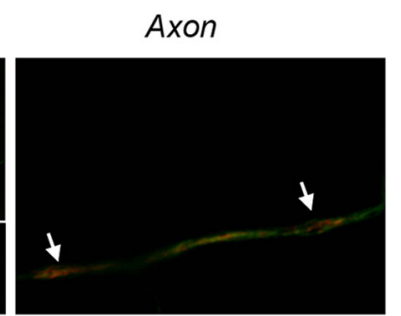

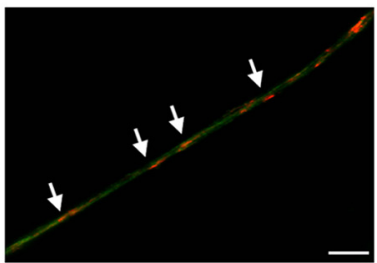

Axonal protein

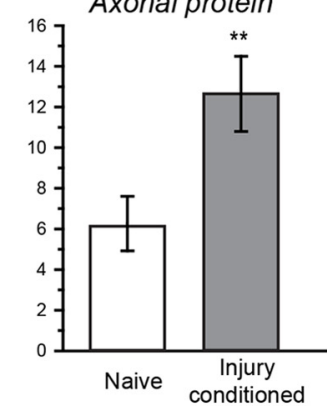

Figure 1. Neuritin mRNA and protein are enriched in axons after injury. $A, R T-P C R$ of cell bodies and axons from naive versus $7 \mathrm{~d}$ injury conditioned DRG cultures shows purity of axonal preparations, with $\gamma$-actin and microtubule-associated protein 2 mRNAs restricted to the cell body. B, C, Shift in Nrn1 mRNA predominance from cell body to axons in injury (Figure legend continues.) 
gen). Reverse transcriptase (RT)-coupled PCR (RT-PCR) and quantitative PCR (RTqPCR) were performed as described previously (Merianda et al., 2013). 12S RNA was used for $\Delta \mathrm{C}_{t}$ calculations (Willis et al., 2007). Primer sequences are available upon request.

Fluorescence in situ hybridization and immunofluorescence. Fluorescence in situ hybridization and immunofluorescence (FISH/IF) was performed as described previously (Merianda et al., 2013) with minor modifications. Cultures were fixed $20 \mathrm{~min}$ in $4 \%$ paraformaldehyde (PFA); tissues were fixed $2 \mathrm{~h}$ in $2 \%$ PFA and processed for cryosectioning. Digoxigenin (Dig)-labeled oligonucleotides were used to detect Nrn1 and cRNA probes were used to detect GFP mRNAs. Probes for Nrn1 have been published (Donnelly et al., 2011). GFP cRNA probes were generated as described previously (Merianda et al., 2013). Scramble oligonucleotide or sense cRNA were used for control.

Primary antibodies were as follows: chick anti-neurofilament (NF) $\mathrm{H}$ (1:500; Millipore) and -NFM (1:500; Aves), and anti-MAP2 (1: 4000; Abcam); mouse anti-Tau (1:1000; Millipore), anti-Dig (for DRGs - 1:200; Jackson ImmunoResearch), and Cy3-anti-Dig (for tissues- 1:200; Jackson ImmunoResearch); rabbit anti-GFP (1:200; Abcam); and sheep anti-Dig (for hippocampi- 1:100; Roche). Secondary antibodies were as follows: Cy5-rabbit anti-chick, Cy3-donkey anti-mouse, FITC-donkey anti-rabbit, and Cy5-donkey anti-sheep (1:200; Jackson ImmunoResearch).

IF was performed as described previously (Merianda et al., 2013), with exception that $4 \%$ PFA fixation was used for tissues and methanol fixation was used for cultures. Goat anti-neuritin (1:200; Neuromics) and chick anti-NFH (1:1000) were used for primary antibodies. Secondary antibodies were as follows: donkey Texas red anti-goat or -mouse (1:300; Jackson ImmunoResearch); and, goat Cy3 anti-mouse and aminomethylcoumarin acetate (AMCA) anti-chick (1:200; Jackson ImmunoResearch). All samples were mounted in Prolong Gold (Invitrogen) and analyzed by epifluorescent or confocal microscopy. Signals were quantitated from exposure-matched images using ImageJ. Image pairs were matched for exposure, gain/offset, and post-processing. For confocal imaging, laser power and photomultiplier tube energy were matched.

Fluorescence recovery after photobleaching. Transfected DRG cultures were used for fluorescence recovery after photobleaching (FRAP; Merianda et al., 2013). Signal intensity normalized to prebleach signals was calculated using ImageJ.

Axon growth analyses. Axon length was analyzed with ImageJ taking the length of axon extending furthest from the cell body (Merianda et al., 2013).

Statistics. Repeated-measures ANOVA with Bonferroni post hoc multiple comparisons was used for FRAP. Student's $t$ test was used to for axon growth, $\mathrm{RTqPCR}$, and image signal intensities.

\section{Results}

Neuritin $m R N A$ is enriched in injured axons

Nrn1 (also called candidate plasticity gene 15' [CPG15]) encodes a glycophosphatidylinositol (GPI)-anchored protein that contributes to synapse formation and maintenance (Nedivi et al., 1996; Naeve et al., 1997; Fujino et al., 2011). Nrn1 mRNA localizes to axons in DRG and hippocampal neurons (Willis et al., 2007; Taylor et al., 2009). Though Nrn1 is not a target for ZBP1, the increased axon growth seen with ZBP1 overexpression in-$$
\leftarrow
$$

(Figure legend continued.) conditioned DRGs is seen both by RT-PCR (B) and RTqPCR ( $\boldsymbol{C}$. Axons of injury conditioned DRGs show $2.75 \pm 0.15$-fold more axonal Nrn1 mRNA than naive. $\boldsymbol{D}, \boldsymbol{E}$, There was no significant difference in overall $\mathrm{Nrn} 1 \mathrm{mRNA}$ (D) or stability of axonal Nrn1 mRNA $(\boldsymbol{E})$ comparing naive and injury conditioned cultures by RTqPCR. RNA stability was tested in axons treated with CSA to delay Wallerian degeneration. $\boldsymbol{F}$, FISH signals for Nrn1 mRNA are higher in the axons (arrows) of injury-conditioned compared with naive DRGs that show more Nrn1 mRNA in cell bodies. G, Neuritin protein is increased in the axons (arrows) and decreased in the cell bodies of the injury conditioned compared with naive DRGS. $\boldsymbol{H}, \boldsymbol{I}$, Quantification of mRNA $(\boldsymbol{H})$ and protein $(\boldsymbol{I})$ signals for cell body and axons are shown $\left({ }^{* *} p \leq 0.01,{ }^{* * * *} p \leq 0.001\right.$, and NS $=$ not significant, as indicated). Scale bars: cell body, $25 \mu \mathrm{m}$; axon, $10 \mu \mathrm{m}$.
}

creased axonal Nrn1 mRNA (Donnelly et al., 2011). Thus, we asked whether Nrn1 localization might be altered by the increased growth seen in injury conditioned DRG cultures (Smith and Skene, 1997). Nrn1 showed increased axonal and decreased cell body levels in cultures of $7 \mathrm{~d}$ injury conditioned compared with naive DRGs (Fig. $1 A-C$ ). There was no difference in overall Nrn1 mRNA levels or survival of axonal Nrn1 mRNA comparing naive and injury conditioned cultures (Fig. $1 D, E$ ). Shift in Nrn1 mRNA from predominantly cell body to predominantly axonal was also seen in the naive versus injury conditioned DRGs by FISH (Fig. $1 F, H$ ). Neuritin protein was similarly increased in axons and decreased in cell bodies of injury conditioned DRGs (Fig. 1G,I).

Looking in vivo, Nrn 1 mRNA was increased in sciatic nerve and decreased in L4-5 DRGs $7 \mathrm{~d}$ after injury, both by RT-PCR and FISH (Fig. $2 A-C$ ). Neuritin protein showed a similar trend, with increase in the sciatic nerve and decrease in the L4-5 DRGs after nerve injury (Fig. 2D). Quantification of confocal images confirmed that L4-5 DRGs had significantly more neuritin mRNA and protein in the naive state, and sciatic nerve axons had significantly more neuritin mRNA and protein after axotomy (Fig. $2 E, F$ ). These data indicate that axotomy triggers a redistribution of neuritin mRNA and protein, from cell body predominant to axon predominant.

\section{Neuritin's 5' UTR drives axonal mRNA localization in \\ DRG neurons}

The 3' UTR of Nrn1 (3'Nrn1) supports localization of GFP mRNA in CNS neurons (Akten et al., 2011). Thus, we used FRAP to ask whether 3'Nrn1 might support translation of GFP in DRG axons. DRG neurons expressing GFP ${ }^{\text {myr }}$ with $5^{\prime}$ UTR of CaMKII $\alpha$ (5' CaMKII $\alpha$ ) and $3^{\prime} \mathrm{Nrn} 1$ (GFP $\left.{ }^{\text {myr }} 5^{\prime} \mathrm{CaMKII} \alpha / 3^{\prime} \mathrm{Nrn} 1\right)$ showed protein synthesis-dependent recovery after photobleaching, but significant recovery was not reached until $30 \mathrm{~min}$ postbleach in the absence of cycloheximide (Fig. 3A).

mRNA sequences other than $3^{\prime}$ UTRs have been shown to contribute to post-transcriptional regulation, including a role in translational efficiency (Bi et al., 2006; Vuppalanchi et al., 2012). To determine whether $5^{\prime} \mathrm{CaMKII} \alpha$ alters translation efficiency in DRG axons, we replaced it with the Nrn1 5' UTR (GFP ${ }^{\text {myr }} 5^{\prime}$ / $3^{\prime} \mathrm{Nrn} 1$ ). Significant recovery was observed by $25 \mathrm{~min}$ in neurons expressing GFP ${ }^{\mathrm{myr}} 5^{\prime} / 3^{\prime} \mathrm{Nrn} 1$, and this was blocked by cycloheximide (Fig. 3B). We next tested whether Nrn1 5' UTR might have localizing activity using a reporter with the nonlocalizing $\gamma$-actin 3' UTR (GFP ${ }^{\mathrm{myr}} 5^{\prime} \mathrm{Nrn} 1 / 3^{\prime} \gamma$-actin; Donnelly et al., 2011). Significant recovery from photobleaching was observed in axons by 20 min with $\mathrm{GFP}^{\mathrm{myr}} 5^{\prime} \mathrm{Nrn} 1 / 3^{\prime} \gamma$-actin, and this was similarly blocked by cycloheximide (Fig. 3C). In contrast to the recovery seen with the $3^{\prime} \mathrm{Nrn} 1$-containing mRNAs, GFP ${ }^{\mathrm{myr}} 5^{\prime} \mathrm{Nrn} 1 / 3^{\prime} \gamma$ actin expressing neurons showed a steady increase in axonal signals over time, with overall higher recovery.

Though fluorescence recovery for each of the Nrn1 UTR reporters required translation, this was delayed compared with other axonal reporter mRNAs (Merianda et al., 2013, and references within). We used FISH to more directly test for axonal GFP mRNA. Axonal mRNA was detected for both $\mathrm{GFP}^{\mathrm{myr}} 5^{\prime} \mathrm{CaMKII} \alpha / 3^{\prime} \mathrm{Nrn} 1$ and $\mathrm{GFP}^{\mathrm{myr}} 5^{\prime} \mathrm{Nrn} 1 / 3^{\prime} \gamma$-actin transfected DRGs (Fig. 3D). However, axonal GFP ${ }^{\mathrm{myr}} 5^{\prime} \mathrm{Nrn} 1 / 3^{\prime} \gamma$-actin mRNA levels were higher than axonal $\mathrm{GFP}^{\mathrm{myr}} 5^{\prime} \mathrm{CaMKII} \alpha / 3^{\prime} \mathrm{Nrn} 1$ mRNA levels (Fig. $3 F$ ). This indicates that differences in overall expression or RNA survival likely account for the higher axonal GFP mRNA in $\mathrm{GFP}^{\mathrm{myr}} 5^{\prime} \mathrm{Nrn} 1 / 3^{\prime} \gamma$ actin expressing DRGs. 
A

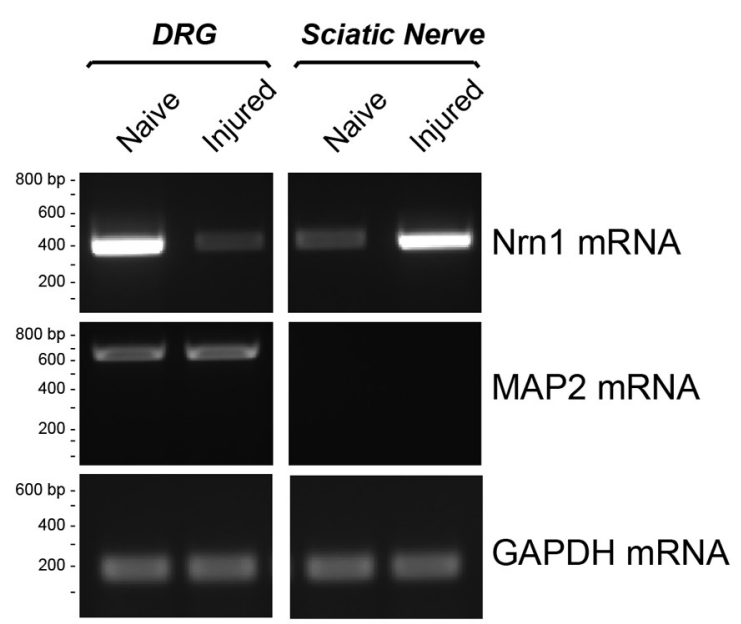

B

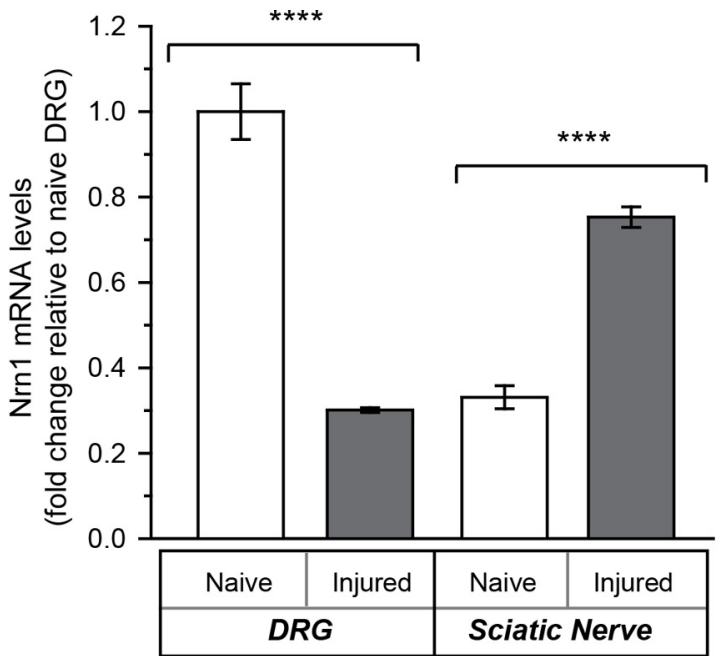

D
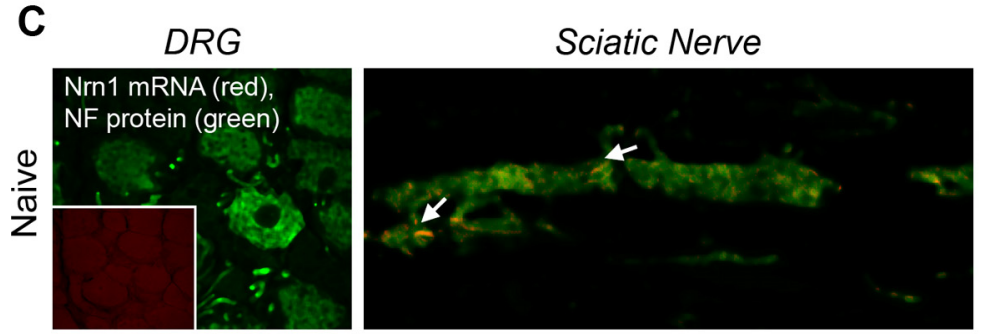

DRG
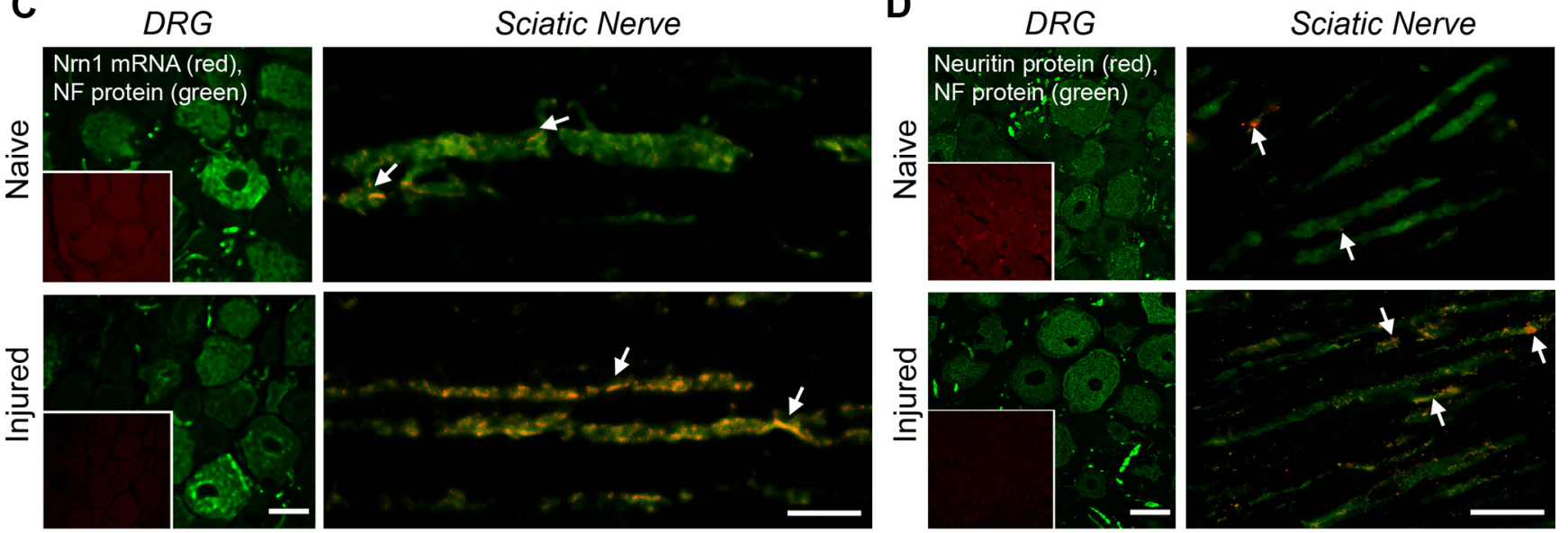

E

DRG $m R N A$

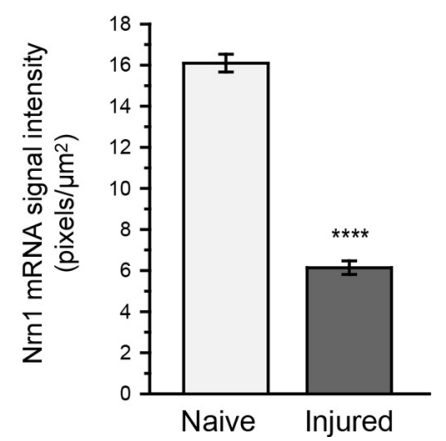

Sciatic

Nerve mRNA

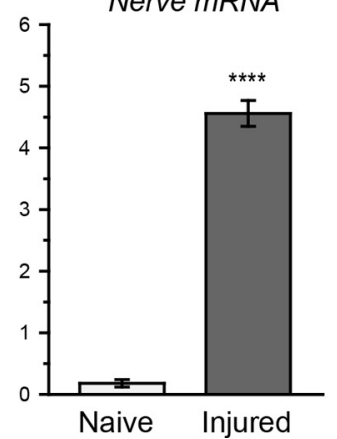

F

F

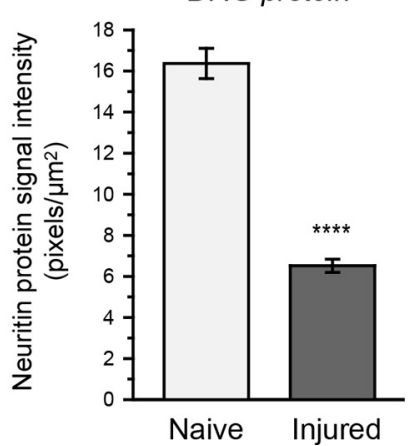

Sciatic Nerve protein

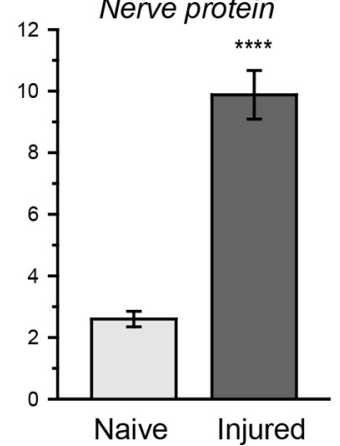

Figure 2. Nerve injury increases axonal neuritin mRNA and protein in vivo. Naive versus $7 \mathrm{~d}$ injured sciatic nerve and L4 5 DRGs were used to assess in vivo levels of neuritin $m R N A$ and protein. $A, B$, Nrm 1 mRNA predominance shifts upon injury, with increased levels in nerve and decreased levels in DRG compared with uninjured rats by RT-PCR. GAPDH shows equal loading and MAP2 is not detected in the nerve consistent with axonal nature of PNS nerve processes. By RTgPCR, injured nerve shows $2.30 \pm 0.02$-fold more Nrn1 mRNA than naive nerve. C, Confocal images of FISH/IF show increased Nrn $1 \mathrm{mRNA}$ in injured nerve axons (arrows) and a decreased Nrn1 mRNA in injured DRG. $\boldsymbol{D}$, Confocal IF images show increased neuritin protein in nerve axons (arrows) and decreased neuritin protein in L4 -5 DRGs after injury. $\boldsymbol{E}$, $\boldsymbol{F}$, Quantification of neuritin mRNA $(\boldsymbol{E})$ and protein $(\boldsymbol{F})$ signals in the DRG versus nerves are shown as indicated ( $\left.{ }^{* * * *} p \leq 0.001\right)$. Scale bars: DRG, $50 \mu \mathrm{m} ;$ nerve, $10 \mu \mathrm{m}$.

Neuritin $5^{\prime}$ UTR is not sufficient for axonal mRNA localization in hippocampal neurons

Considering that the $5^{\prime} \mathrm{Nrn} 1$ drives localization into DRG axons, we asked whether it has any localizing activity in CNS neurons. Hippocampal neurons expressing $\mathrm{GFP}^{\mathrm{myr}} 5^{\prime} \mathrm{Nrn} 1 / 3^{\prime} \gamma$-actin or GFP ${ }^{\mathrm{myr}} 5^{\prime} \mathrm{CaMKII} \alpha / 3^{\prime} \mathrm{Nrn} 1$ showed axonal GFP mRNA signals (Fig. 3E). However, GFP ${ }^{\text {myr }} 5^{\prime} \mathrm{CaMKII} \alpha / 3^{\prime} \mathrm{Nrn} 1$ expressing neurons showed higher axonal GFP mRNA levels than neurons expressing
$\mathrm{GFP}^{\mathrm{myr}} 5^{\prime} \mathrm{Nrn} 1 / 3^{\prime} \gamma$-actin (Fig. $3 G$ ). Dendritic FISH signals showed no significant differences (Fig. $3 G$ ), suggesting that differences in polarity between the hippocampal and DRG neurons do not account for the different UTR localizing activities.

Axonally localized neuritin mRNA increases axonal growth Because axonal levels of Nrn1 mRNA increased after injury, we asked whether neuritin protein might contribute to neurite 
A GFP'mrr-5'CaMKIlo/3'Nrn1

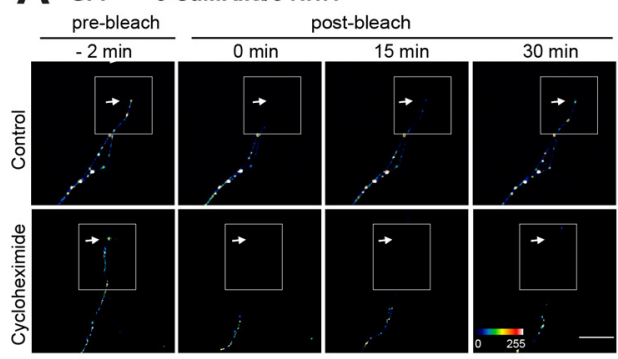

B GFP'Prr-5/3'Nrn1

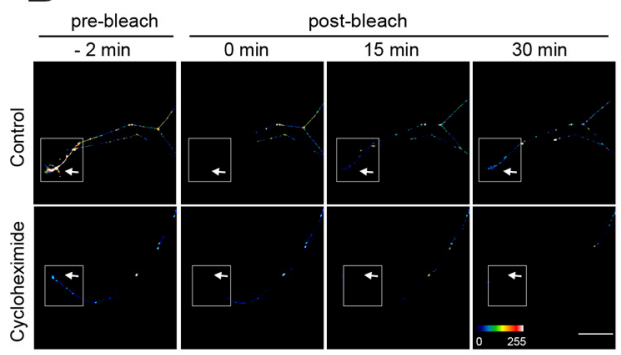

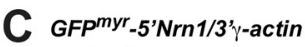

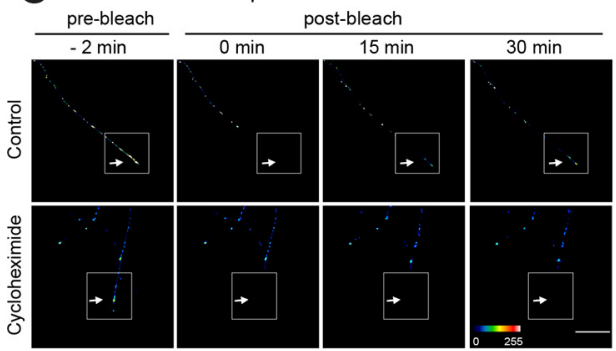

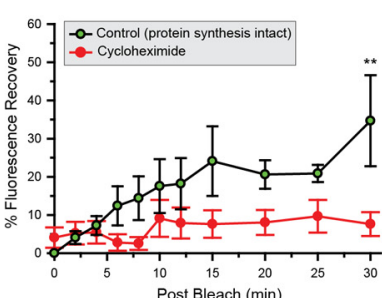

E
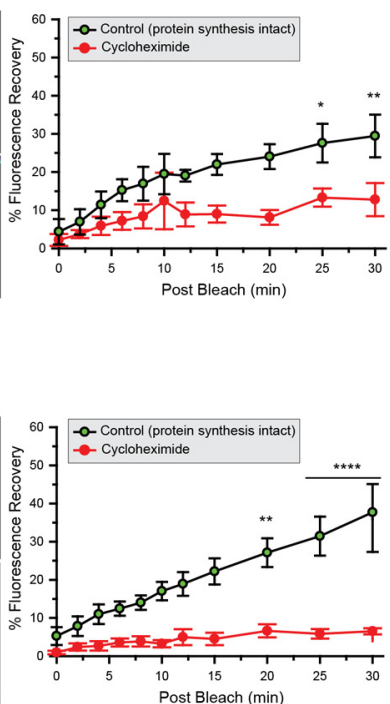

$\mathbf{F}$
D
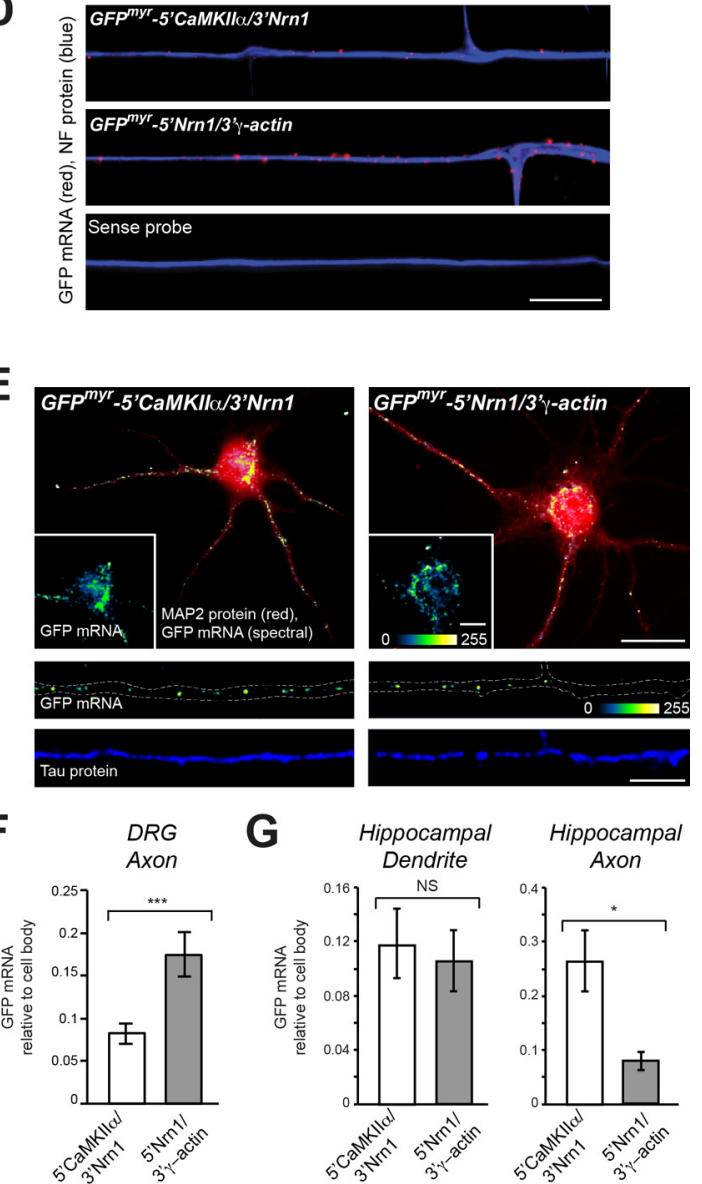

Figure 3. Neuritin $5^{\prime}$ and $3^{\prime}$ UTRs have distinct localization activities. $A-C$, Representative FRAP image sequences with corresponding quantification of recovery are shown. Bleached ROls are indicated (boxes). Fluorescence intensity relative to prebleach for ROIs is shown as average \pm SEM ( $N \geq 6$ over at least 3 separate cultures; ${ }^{*} p \leq 0.05,{ }^{* *} p \leq 0.01,{ }^{* * * *} p \leq$ 0.001 for indicated value vs $t=0 \mathrm{~min}$ ). D, FISH/IF images for axon shaft of DRG neurons transfected with the indicated constructs are shown. Hybridization with sense GFP probe shows specificity. E, FISH/IF images for hippocampal neurons expressing indicated constructs are shown. Soma and dendrites (top row) were detected by MAP2 IF; axons were detected by Tau IF (middle and bottom row). GFP mRNA signals are shown as indicated spectrum; insets show RNA for cell bodies. Outline of Tau signal is provided on the RNA panel to highlight boundaries of the axon. $\boldsymbol{F}, \boldsymbol{G}$, Quantifications of GFP mRNA in DRG axons $(\boldsymbol{F})$ and hippocampal axons and dendrites $(\boldsymbol{G})$ are shown as average \pm SEM relative to cell body GFP $m R N A(N \geq$ 30 processes in three experiments; ${ }^{*} p \leq 0.05,{ }^{* * *} p \leq 0.005$, NS $=$ not significant). Scale bars: $\boldsymbol{A}-\boldsymbol{C}, 25 \mu \mathrm{m} ; \boldsymbol{D}, 10 \mu \mathrm{m} ; \boldsymbol{E}$, top row, $20 \mu \mathrm{m} ; \boldsymbol{E}$, bottom row, $10 \mu \mathrm{m}$.

growth. Depletion of Nrn1 mRNA from DRG neurons reduced axon length by $>80 \%$ (Fig. $4 A, B$ ). To determine whether axonally targeted Nrn1 might alter axon growth, we generated neuritin-GFP fusion constructs with different UTR combinations. DRGs transfected with neuritin-GFP-5'/ 3'GFP, neuritin-GFP-5'/3'Nrn1, neuritin-GFP-5'GFP/3' Nrn1, and neuritin-GFP-5'Nrn1/3'GFP showed approximately equal levels of GFP mRNA (Fig. 4C). These transfected DRGs also showed the predicted molecular weight for the NeuritinGFP protein by immunoblotting (data not shown). By FISH analyses, neuritin-GFP-5'/3' $\mathrm{Nrn} 1$ and $-5^{\prime} \mathrm{Nrn} 1 / 3^{\prime}$ GFP showed robust axonal GFP mRNA signals, neuritin-GFP-5'GFP/3'Nrn 1 showed low axonal GFP mRNA signals, and neuritin-GFP-5'/ $3^{\prime}$ GFP showed no axonal GFP mRNA signals (Fig. 4D). Axon growth from these transfected DRGs paralleled the localizing activities of $5^{\prime} \mathrm{Nrn} 1$ and $3^{\prime} \mathrm{Nrn} 1$. DRGs expressing neuritinGFP- $5^{\prime} / 3^{\prime} \mathrm{Nrn} 1$ or neuritin-GFP-5 ${ }^{\prime} \mathrm{Nrn} 1 / 3^{\prime}$ GFP showed longer axons than those transfected with GFP or neuritin-GFP-5'/ 3'GFP (Fig. 4E, F). Neurons expressing neuritin-GFP-5'GFP/ $3^{\prime} \mathrm{Nrn} 1$ showed a small increase in axon length compared with GFP or neuritin-GFP-5'/3'GFP.

\section{Discussion}

The work here shows the first example for different UTR elements driving localization of a single mRNA in different neuronal types. We previously reported that calreticulin's 3' UTR has two distinct localization elements, but these showed no specificity between PNS and CNS neurons (Vuppalanchi et al., 2010). Calreticulin's 5' UTR has regulatory activity, but it is used for translational control rather than localization (Vuppalanchi et al., $2012)$. Both $5^{\prime}$ and $3^{\prime}$ UTRs of the $\kappa$-opioid receptor $(\kappa \mathrm{OR})$ mRNA have axonal localizing activity (Bi et al., 2006). Similar to $\mathrm{Nrn1}$, there was higher axonal reporter mRNA translation with $\kappa \mathrm{OR} 5^{\prime}$ UTR compared with $\kappa$ OR 3' UTR; however, $\kappa$ OR 3' UTR had equivalent mRNA localizing capability, suggesting that the $\kappa \mathrm{OR} 5^{\prime}$ UTR also provides more efficient translation (Bi et al., 2006). In contrast, Nrn 1's $5^{\prime}$ and $3^{\prime}$ UTRs have differential activity in DRG versus hippocampal axons. Though we cannot completely exclude that survival differences for localized $\mathrm{GFP}^{\mathrm{myr}} 5^{\prime} \mathrm{Nrn} 1 / 3^{\prime} \mathrm{GFP}$ and $\mathrm{GFP}^{\mathrm{myr}} 5^{\prime} \mathrm{CaMKII} \alpha / 3^{\prime} \mathrm{Nrn} 1 \mathrm{mRNAs}$ contribute to the differences in the DRGs versus hippocampal axons, our data show clearly distinct use of these UTRs by PNS and CNS neurons. 

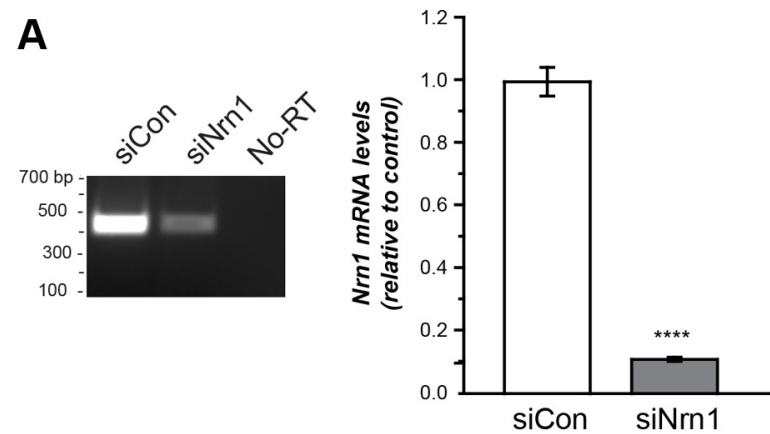

B

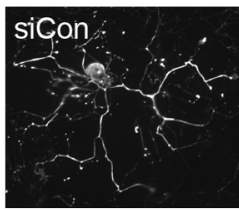

siNrn1
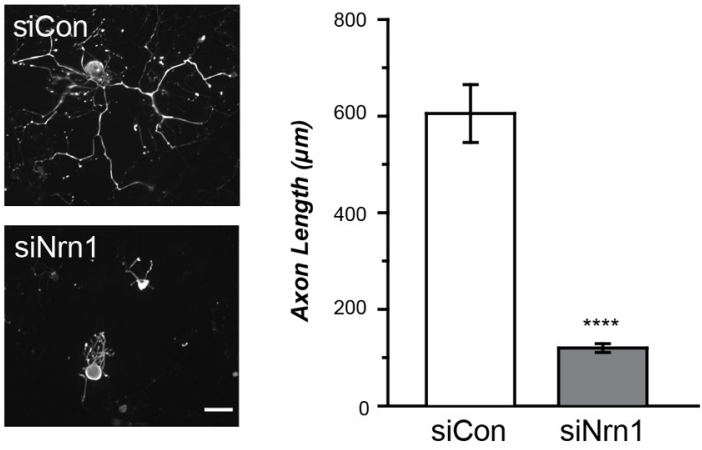

C

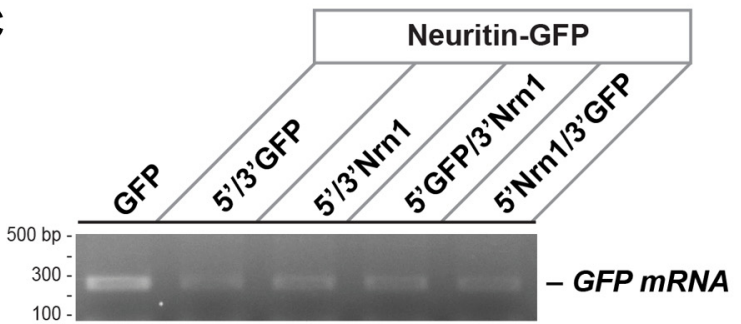

E

NF protein

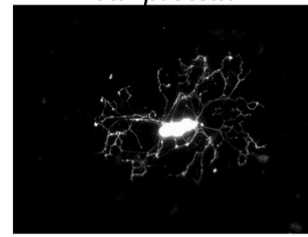

Neuritin-GFP. 5'/3'GFP

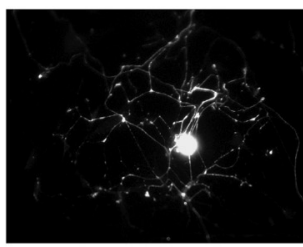

Neuritin-GFP. 5'GFP/3'Nrn1
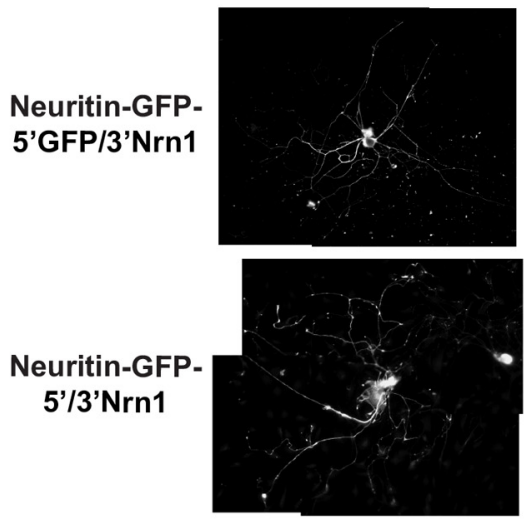

Neuritin-GFP. 5'Nrn1/3'GFP
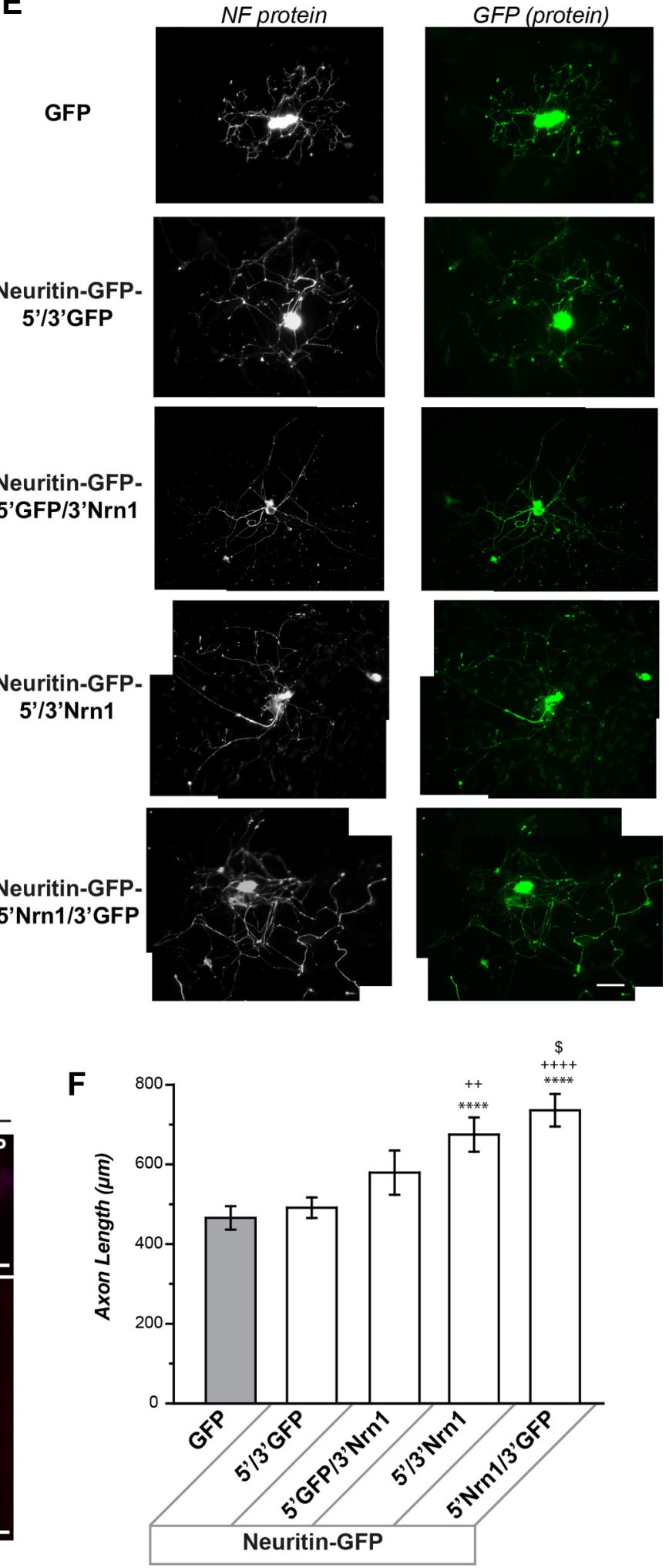

D

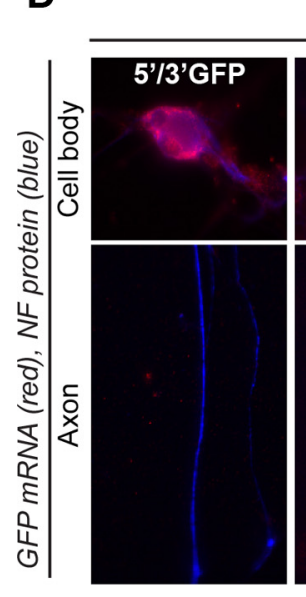

Neuritin-GFP

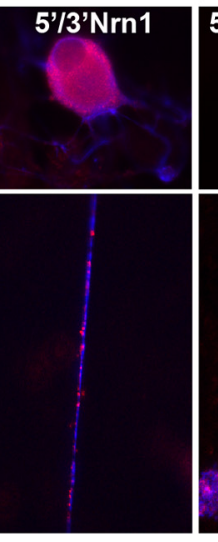

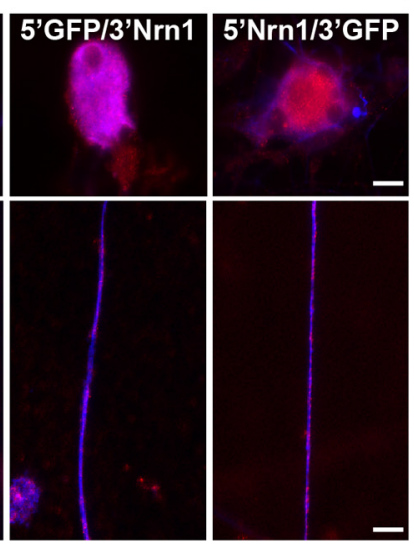

Figure 4. Axonally targeted neuritin-GFP increases axon growth. $A$, DRG cultures transfected with Nrn1 siRNA (siNrn1) show decreased Nrn1 mRNA levels by standard RT-PCR (left) and RTqPCR (right) versus control siRNA (siCon; ${ }^{* * * *} p \leq 0.001$ ). $\boldsymbol{B}$, Representative images (left) and average axon length \pm SEM (right) are shown for siNrn1 versus siCon transfected DRGs ( $N \geq 30$ neurons in three experiments; ${ }^{* * *} p \leq 0.001$ ). C, Nrn1 and GFP mRNA was detected by RT-PCR using RNA from transfected DRGs. D, Exposure matched FISH/IF images for cell body (top) and axonal shaft (bottom) of transfected DRGs are shown. $\boldsymbol{E}$, Montage images are shown for NFH- and GFP-stained neurons expressing indicated constructs. $\boldsymbol{F}$, Average axon length \pm SEM for DRG neurons expressing neuritin-GFP fusion constructs versus GFP is shown ( $N \geq 30$ neurons in at least three experiments; ${ }^{* * *} p \leq 0.001$ for indicated values versus GFP; $++++p \leq 0.001$ for indicated values versus neuritin-GFP-5'/3'GFP; and, $\$ p \leq 0.05$ for indicated values versus neuritin-GFP-5'GFP/3' Nrn1). Scale bars: $\boldsymbol{B}, \boldsymbol{E}, 50 \mu \mathrm{m} ; \mathbf{C}^{\prime}$, cell body, $20 \mu \mathrm{m} ; C$, axons, $10 \mu \mathrm{m}$. 
Different RNA binding proteins recognizing the $5^{\prime} \mathrm{Nrn} 1$ versus $3^{\prime} \mathrm{Nrn} 1$ could explain these distinct activities. Survival of motor neuron (SMN) has been shown to colocalize with Nrn1 mRNA in hippocampal axons, and SMN and HuD immunoprecipitates from brain contain Nrn1 mRNA (Akten et al., 2011). HuD is well established as an RNA binding protein that recognizes adenylate and uridylate-rich elements (AREs; Bolognani et al., 2010). Thus, HuD may bind directly to $3^{\prime} \mathrm{Nrn} 1$ in CNS neurons. HuD directly binds to GAP-43 mRNA's ARE (Chung et al., 1997), and this element is sufficient for axonal localization in DRGs (Yoo et al., 2013). Because HuD clearly expressed in DRGs and apparently contributes to GAP-43 mRNA localization (Yoo et al., 2013), then other factors must be present in the hippocampal neurons to account for activity of $3^{\prime} \mathrm{Nrn} 1$. Similarly, other RNA binding proteins must account for activity of $5^{\prime} \mathrm{Nrn} 1$ for localization in the DRGs.

Nrn1 was initially identified as a light-responsive gene in the visual cortex (Nedivi et al., 1996) and a kainate-induced gene in the hippocampus (Naeve et al., 1997). Subsequent studies pointed Nrn1's role in synapse development, synapse stability, and neurite growth (Loebrich and Nedivi, 2009, and references within). Overexpression of Nrn1 in Xenopus motor neurons promotes axonal growth (Javaherian and Cline, 2005), and exogenous neuritin increases neurite outgrowth from cultured neurons (Naeve et al., 1997; Fujino et al., 2008). Effects of exogenous neuritin on neurite growth could point to paracrine or autocrine growth-promoting activities for the endogenous protein. Axonal synthesis of neuritin protein shown here would provide a spatially restricted mechanism for this axonal growth promotion. Overall levels of Nrn1 mRNA increase after spinal cord injury, cerebral ischemia, and axotomy of motor neurons (Di Giovanni et al., 2005; Han et al., 2007; Rickhag et al., 2007; Fargo et al., 2008). Although we see no increase in Nrn1 mRNA in the DRG following sciatic nerve crush, upregulation of Nrn1 in these other injuries could set the stage for an increase in locally generated neuritin given that the molecular machinery needed for its transport into axons is not limiting as seen for other axonal mRNAs (Donnelly et al., 2011, 2013).

\section{References}

Aakalu G, Smith WB, Nguyen N, Jiang C, Schuman EM (2001) Dynamic visualization of local protein synthesis in hippocampal neurons. Neuron 30:489-502. CrossRef Medline

Akten B, Kye MJ, Hao le T, Wertz MH, Singh S, Nie D, Huang J, Merianda TT, Twiss JL, Beattie CE, Steen JA, Sahin M (2011) Interaction of survival of motor neuron (SMN) and HuD proteins with mRNA cpg 15 rescues motor neuron axonal deficits. Proc Natl Acad Sci U S A 108: 10337-10342. CrossRef Medline

An JJ, Gharami K, Liao GY, Woo NH, Lau AG, Vanevski F, Torre ER, Jones KR, Feng Y, Lu B, Xu B (2008) Distinct role of long 3' UTR BDNF mRNA in spine morphology and synaptic plasticity in hippocampal neurons. Cell 134:175-187. CrossRef Medline

Bi J, Tsai NP, Lin YP, Loh HH, Wei LN (2006) Axonal mRNA transport and localized translational regulation of kappa-opioid receptor in primary neurons of dorsal root ganglia. Proc Natl Acad Sci U S A 103: 19919-19924. CrossRef Medline

Bolognani F, Contente-Cuomo T, Perrone-Bizzozero NI (2010) Novel recognition motifs and biological functions of the RNA-binding protein $\mathrm{HuD}$ revealed by genome-wide identification of its targets. Nucleic Acids Res 38:117-130. CrossRef Medline

Chung S, Eckrich M, Perrone-Bizzozero N, Kohn DT, Furneaux H (1997) The Elav-like proteins bind to a conserved regulatory element in the 3 '-untranslated region of GAP-43 mRNA. J Biol Chem 272: 6593-6598. CrossRef Medline

Di Giovanni S, Faden AI, Yakovlev A, Duke-Cohan JS, Finn T, Thouin M,
Knoblach S, De Biase A, Bregman BS, Hoffman EP (2005) Neuronal plasticity after spinal cord injury: identification of a gene cluster driving neurite outgrowth. FASEB J 19:153-154. CrossRef Medline

Donnelly CJ, Willis DE, Xu M, Tep C, Jiang C, Yoo S, Schanen NC, KirnSafran CB, van Minnen J, English A, Yoon SO, Bassell GJ, Twiss JL (2011) Limited availability of ZBP1 restricts axonal mRNA localization and nerve regeneration capacity. EMBO J 30:4665-4677. CrossRef Medline

Donnelly CJ, Park M, Spillane M, Yoo S, Pacheco A, Gomes C, Vuppalanchi D, McDonald M, Kim HH, Merianda TT, Gallo G, Twiss JL (2013) Axonally synthesized beta-actin and GAP-43 proteins support distinct modes of axonal growth. J Neurosci 33:3311-3322. CrossRef Medline

Fargo KN, Alexander TD, Tanzer L, Poletti A, Jones KJ (2008) Androgen regulates neuritin mRNA levels in an in vivo model of steroid-enhanced peripheral nerve regeneration. J Neurotrauma 25:561-566. CrossRef Medline

Fujino T, Wu Z, Lin WC, Phillips MA, Nedivi E (2008) cpg15 and cpg15-2 constitute a family of activity-regulated ligands expressed differentially in the nervous system to promote neurite growth and neuronal survival. J Comp Neurol 507:1831-1845. CrossRef Medline

Fujino T, Leslie JH, Eavri R, Chen JL, Lin WC, Flanders GH, Borok E, Horvath TL, Nedivi E (2011) CPG15 regulates synapse stability in the developing and adult brain. Genes Devel 25:2674-2685. CrossRef Medline

Gomes C, Smith SC, Youssef MN, Zheng JJ, Hagg T, Hetman M (2011) RNA polymerase 1-driven transcription as a mediator of BDNF-induced neurite outgrowth. J Biol Chem 286:4357-4363. CrossRef Medline

Han Y, Chen X, Shi F, Li S, Huang J, Xie M, Hu L, Hoidal JR, Xu P (2007) CPG15, a new factor upregulated after ischemic brain injury, contributes to neuronal network re-establishment after glutamate-induced injury. J Neurotrauma 24:722-731. CrossRef Medline

Javaherian A, Cline HT (2005) Coordinated motor neuron axon growth and neuromuscular synaptogenesis are promoted by CPG15 in vivo. Neuron 45:505-512. CrossRef Medline

Jung H, Yoon BC, Holt CE (2012) Axonal mRNA localization and local protein synthesis in nervous system assembly, maintenance and repair. Nat Rev Neurosci 13:308-324. CrossRef Medline

Loebrich S, Nedivi E (2009) The function of activity-regulated genes in the nervous system. Physiol Rev 89:1079-1103. CrossRef Medline

Merianda TT, Vuppalanchi D, Yoo S, Blesch A, Twiss JL (2013) Axonal transport of neural membrane protein 35 mRNA increases axon growth. J Cell Sci 126:90-102. CrossRef Medline

Naeve GS, Ramakrishnan M, Kramer R, Hevroni D, Citri Y, Theill LE (1997) Neuritin: a gene-induced by neural activity and neurotrophins that promotes neuritogenesis. Proc Natl Acad Sci US A 94: 2648-2653. CrossRef Medline

Nedivi E, Fieldust S, Theill LE, Hevron D (1996) A set of genes expressed in response to light in the adult cerebral cortex and regulated during development. Proc Natl Acad Sci U S A 93:2048-2053. CrossRef Medline

Perry RB, Doron-Mandel E, Iavnilovitch E, Rishal I, Dagan SY, Tsoory M, Copolla G, Gomes C, McDonald MK, Geschwind DH, Twiss JL, Yaron A, Fainzilber M (2012) Subcellular knock-out of importin $\beta 1$ perturbs axonal retrograde signaling. Neuron 75:294-305. CrossRef Medline

Rickhag M, Teilum M, Wieloch T (2007) Rapid and long-term induction of effector immediate early genes (BDNF, neuritin and Arc) in peri-infarct cortex and dentate gyrus after ischemic injury in rat brain. Brain Res 1151:203-210. CrossRef Medline

Smith DS, Skene JH (1997) A transcription-dependent switch controls competence of adult neurons for distinct modes of axon growth. J Neurosci 17:646-658. Medline

Taylor AM, Berchtold NC, Perreau VM, Tu CH, Li Jeon N, Cotman CW (2009) Axonal mRNA in uninjured and regenerating cortical mammalian axons. J Neurosci 29:4697-4707. CrossRef Medline

Tiruchinapalli DM, Oleynikov Y, Kelic S, Shenoy SM, Hartley A, Stanton PK, Singer RH, Bassell GJ (2003) Activity-dependent trafficking and dynamic localization of zipcode binding protein 1 and beta-actin mRNA in dendrites and spines of hippocampal neurons. J Neurosci 23:3251-3261. Medline

Twiss JL, Smith DS, Chang B, Shooter EM (2000) Translational control of ribosomal protein L4 is required for rapid neurite extension. Neurobiol Dis 7:416-428. CrossRef Medline 
Vuppalanchi D, Coleman J, Yoo S, Merianda TT, Yadhati AG, Hossain J, Blesch A, Willis DE, Twiss JL (2010) Conserved 3'-untranslated region sequences direct subcellular localization of chaperone protein mRNAs in neurons. J Biol Chem 285:18025-18038. CrossRef Medline

Vuppalanchi D, Merianda TT, Donnelly C, Pacheco A, Williams G, Yoo S, Ratan RR, Willis DE, Twiss JL (2012) Lysophosphatidic acid differentially regulates axonal mRNA translation through $5^{\prime}$ UTR elements. Mol Cell Neurosci 50:136-146. CrossRef Medline

Willis DE, van Niekerk EA, Sasaki Y, Mesngon M, Merianda TT, Williams GG, Kendall M, Smith DS, Bassell GJ, Twiss JL (2007) Extracellular stimuli specifically regulate localized levels of individual neuronal mRNAs. J Cell Biol 178:965-980. CrossRef Medline

Willis DE, Xu M, Donnelly CJ, Tep C, Kendall M, Erenstheyn M, English AW, Schanen NC, Kirn-Safran CB, Yoon SO, Bassell GJ, Twiss JL (2011) Ax- onal localization of transgene mRNA in mature PNS and CNS neurons. J Neurosci 31:14481-14487. CrossRef Medline

Yoo S, Kim H, Kim P, Donnelly CJ, Kalinski A, Vuppalanchi D, Park M, Lee SJ, Merianda TT, Perrone-Bizzozero N, Twiss JL (2013) A HuD-ZBP1 ribonucleoprotein complex localizes GAP-43 mRNA into axons through its $3^{\prime}$ untranslated region AU-rich regulatory element. J Neurochem. Advance online publication. doi:10.1111/jnc.12266. CrossRef Medline

Zhang HL, Eom T, Oleynikov Y, Shenoy SM, Liebelt DA, Dictenberg JB, Singer RH, Bassell GJ (2001) Neurotrophin-induced transport of a betaactin mRNP complex increases beta-actin levels and stimulates growth cone motility. Neuron 31:261-275. CrossRef Medline

Zheng JQ, Kelly TK, Chang B, Ryazantsev S, Rajasekaran AK, Martin KC, Twiss JL (2001) A functional role for intra-axonal protein synthesis during axonal regeneration from adult sensory neurons. J Neurosci 21:9291-9303. Medline 